
www.globaliournalseries.com, Email: info@globaljournalseries.com

\title{
HYDROGEOPHYSICAL INVESTIGATION OF THE AREA AROUND ANGWARE IN JOS EAST PLATEAU STATE, NORTH CENTRAL NIGERIA.
}

E. Y. MBIIMBE, A. OLASEHINDE AND I. S. BUTE

(Received 4 June 2012; Revision Accepted 11 October 2012)

\begin{abstract}
Hydrogeophysical investigation of the area around Angware and its environs was carried out. It is about $25 \mathrm{~km}^{2}$ and lies between latitudes $10^{\circ} 00^{\prime} \mathrm{N}$ and $9^{\circ} 58^{\prime} \mathrm{N}$ and longitudes $9^{\circ} 05^{\prime} \mathrm{E}$ and $9^{\circ} 08^{\prime} \mathrm{E}$. Schlumberger resistivity configuration method was used and interpreted with IP2Win 2.1 program. Geologically is underlain by Precambrian Basement complex $(600 \pm 150 \mathrm{Ma})$ and Mesozoic Younger Granites(130-150Ma).Computer aided results showed that the area is characterized by seven curve-types $(\mathrm{A}, \mathrm{H}, \mathrm{Q}, \mathrm{HA}, \mathrm{QH}, \mathrm{KA}$ and $\mathrm{QK})$ and 3,4 and 5 geo-electric layers with resistivity range and thickness of 100-692 m,1.4-51m; 15.7-1300 m,0.9-84m; and 72-504 m,0.9-36m respectively. The aquiferous zone revealed by the results is weathered/fractured Basement at a depth between $10-35 \mathrm{~m}$ and resistivity range from $18-107 \mathrm{~m}$, drilling depth of $20-45 \mathrm{~m}$ is recommended for maximum yields.
\end{abstract}

KEY WORDS: Hydro Geophysical, Angware, Aquifer, Geo-Electric

\section{INTRODUCTION}

The nature of groundwater occurrence and distribution in typical Basement terrains is more complex due to the discontinuous pattern of crystalline aquifers. Successful groundwater development in such areas requires a quantitative knowledge of the hydrogeophysical parameters of the hydro-geologic units as well as the superficial materials overlying the crystalline rocks and the bedrock structures/relief, (Omosuyi et al, 2003; Olorunfemi et al, 1999 and Jeff, 2006). Ground water development in areas of crystalline rocks depends on the climatic factors such as temperature, rainfall, humidity, relief and vegetation (Offodile, 2002).

In this study a detailed hydrogeophysical investigation of Angware and environs was carried out with a view of determining the geo-electric parameters (layer resistivity, thickness and aquifer potentials) of the superficial/overburden materials overlying the bedrock, the subsurface structural disposition of the bedrock and their hydrogeologic characteristics. The nature of the regolith materials overlying the bed rock in the study area is very influential in defining the groundwater potentials of the area. Vertical electrical sounding conducted in about thirty points was interpreted to establish the control of hydrogeophysics on the occurrence and distribution of groundwater in Angware area.

\section{Geology of the Study area}

The study area is located in Jos East Local Government Area (L.G.A) of Plateau State. It lies between latitudes $10^{\circ} 00^{\prime} \mathrm{N}$ and $9^{\circ} 58^{\prime} \mathrm{N}$ and longitudes $9^{\circ} 05^{\prime} \mathrm{E}$ and $9^{\circ} 08^{\prime} \mathrm{E}$. The study area is part of maijuju sheet. Geologically the study area is underlain by Precambrian Basement Complex $(600 \pm 150 \mathrm{ma})$ and later intrusion of Mesozoic Younger Granites (130-150ma) as given by various workers including McLeod et al (1971), McCurry (1989), and Turner (1989). The study area is situated between the Shere Hills and Jarawa hills constituted by Undifferentiated Migmatites, Hornblende Biotite, Granite Porphyry, Older Biotite Granite, Early Rhyolite and Aplitic Pegmatite. (Fig. 1)

E.Y. Mbiimbe, Department of Geology, Gombe State University, Gombe, Nigeria

A. Olasehinde, Department of Geology, Gombe State University, Gombe, Nigeria

I. S. Bute, Department of Geology, Gombe State University, Gombe, Nigeria 

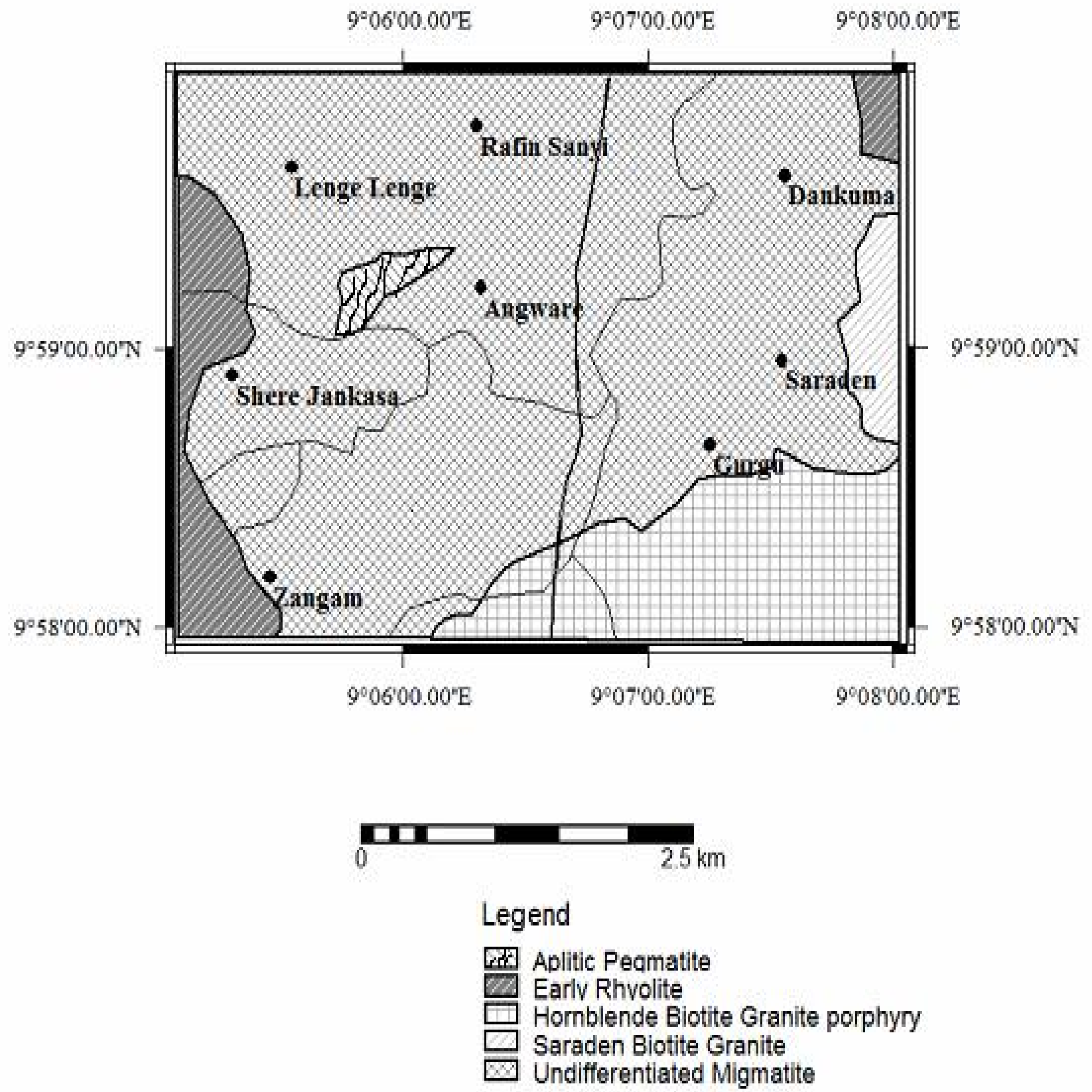

Figure 1. The Geological map of the study area

\section{Materials and methods}

The study was conducted in two phases; the geologic mapping preceded the hydrogeophysical investigation and was designed to collect and analyze rock samples with the aim of delineating areas with potentials of high yielding water wells. With the geology clearly established hydrogeophysical soundings were carried out at points well distributed to capture all the geologic Formations underlying the area. The main reason behind this approach was to bring out the geologic control on the hydrogeophysical parameters of significance in the groundwater occurrence and distribution. A total of twenty five probe points were investigated using campus allied ohmega resistivity, model number: 034CE to generate data on geoelectric layers, their resistivity, depths and thicknesses.(Fig 2) Plots of such data produced different type curves ranging from Q-type curve, K-type curve, $\mathrm{H}$ - type curve 
A-type curve and combination of some of the type curves. The IPI2Win 2.1 version computer program was used to expedite the interpretation after manual partial curve matching. These data were interpreted to separate geologic units into aquiferous and non aquiferous.
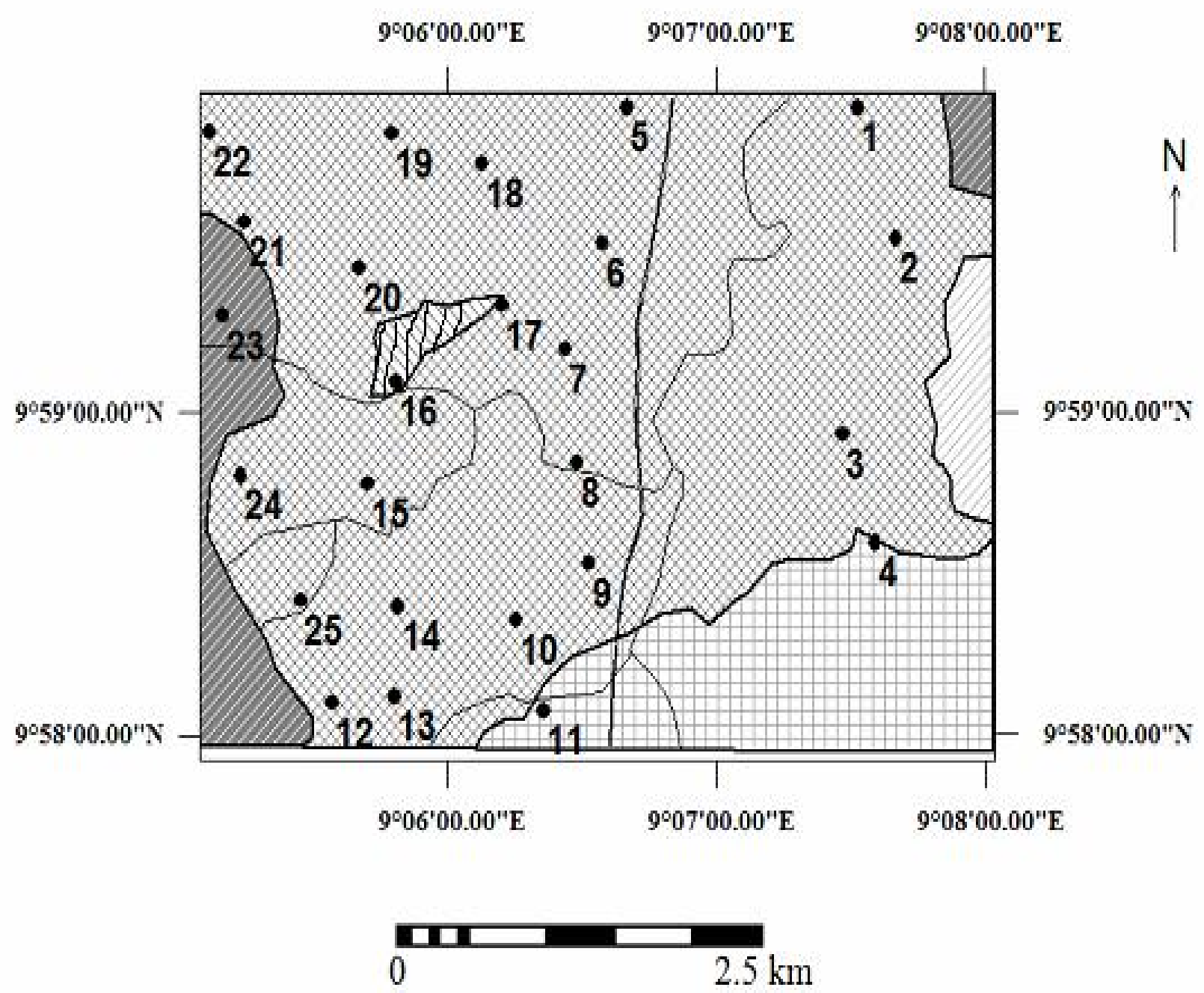

Legend

Aplitic Pegmatite

$\square$ Early Rhyolite

Homblende Biotite Granite porphyry

Saraden Biotite Granite

Undifferentiated Migmatite

- Main Road

- Rivers

- VES point

Figure 2. The map of the study area showing VES points 


\section{RESULTS}

The twenty five vertical electric sounding (VES) data acquired were processed using the partial curve matching method and computer interpreted curves. The result is presented on table1. The geo-electric layers range from three to five and the characteristic VES curves are shown in figures 3.0-3.2

Table 1: Interpreted Results of Field Data

\begin{tabular}{|c|c|c|c|c|c|c|c|c|c|c|c|c|c|}
\hline $\mathrm{S} / \mathrm{NO}$ & VES & THICKNES & SS OF LAYER & $\mathrm{RS}(\mathrm{M})$ & & & RESISTIVITY C & OF LAYER & RS (OHM-N & & & CURVE-TYPE & FITTING ERROR(\%) \\
\hline & & h1 & h2 & h3 & h4 & h5 & p1 & p2 & p3 & p4 & p5 & & \\
\hline & 1|VES1 & 1.67 & 4.85 & $\begin{array}{ll} & 84.18 \\
\end{array}$ & & - & 473 & \begin{tabular}{|l|}
194.8 \\
\end{tabular} & 105.1 & \begin{tabular}{|l|} 
\\
\end{tabular} & & Q & 0.752 \\
\hline & \begin{tabular}{|l|l|}
2 & VES2
\end{tabular} & 1.31 & 3.89 & 5.589 & & & 15.03 & 73.54 & 15.7 & 175.23 & & A & 0.546 \\
\hline & \begin{tabular}{l|l|l|}
3 & VES3 \\
\end{tabular} & 0.89 & 1.08 & 17.61 & & - & 40.22 & 8.34 & 112.8 & 131.83 & & HA & 0.0674 \\
\hline & \begin{tabular}{l|l|l|}
4 & VESS
\end{tabular} & 1.35 & 15 & & F. & - & 586.1 & 246.4 & 397.5 & & & $\mathrm{H}$ & 0.0188 \\
\hline & 5 VES5 & 3.78 & 12.2 & & & - & 374.4 & 25.85 & 183.5 & & & $\mathrm{H}$ & 0.313 \\
\hline & \begin{tabular}{l|l}
6 & VES6 \\
\end{tabular} & 1.09 & 12.2 & & $E$ & - & 374.9 & 232.5 & 100 & & - & Q & 0.0265 \\
\hline & \begin{tabular}{l|l|}
77 & VES7
\end{tabular} & 2.11 & 2.03 & 21.7 & & - & 262.3 & 26.47 & 125.8 & 125.4 & & $\mathrm{H}$ & 0.0623 \\
\hline & \begin{tabular}{|l|l|}
8 VES8 \\
\end{tabular} & 0.31 & 18.8 & & F. & - & 115.2 & 51.5 & 144.8 & & & $\mathrm{H}$ & 0.215 \\
\hline & 9 VES9 & 1.86 & 10.1 & 10.3 & & - & 1300 & 274 & 18.1 & 245.6 & & $\mathrm{QH}$ & 0.106 \\
\hline & 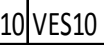 & 1.75 & 8.72 & 14.06 & & - & 924.5 & 181.7 & 41.11 & 745 & & $\mathrm{H}$ & 0.111 \\
\hline & 11 VES11 & 1.73 & 5.59 & 13.96 & 26 & & 89.98 & 40.57 & 20.46 & 73.15 & & QK & 0.351 \\
\hline & \begin{tabular}{|l|l|}
12 & $V E S 12$ \\
\end{tabular} & 0.7 & 0.61 & 60.95 & & - & 508.6 & 204.6 & 474.5 & 9.207 & & $Q$ & 0.302 \\
\hline & \begin{tabular}{|l|l|}
13 & VES13
\end{tabular} & 0.96 & 7 & 68.25 & & - & 990.6 & 538.2 & 19.6 & 42.77 & & Q & 0.0986 \\
\hline & \begin{tabular}{l|l|l|}
14 & VES14 \\
\end{tabular} & 2.12 & 4.91 & 11.46 & 27 & & 1004 & 377.7 & 24.67 & 656.2 & & KA & 1.46 \\
\hline & $\begin{array}{l}15 \\
\text { VES15 }\end{array}$ & 1.15 & 8.87 & 13.85 & & - & 724.9 & 202 & 14.7 & 476.3 & & $\mathrm{QH}$ & 0.166 \\
\hline & $16 \mid$ VES16 & 3.07 & 9.74 & 10.83 & & - & 804.8 & 516.7 & 32.59 & 677 & & KA & 0.179 \\
\hline & $\begin{array}{ll}17 & \text { VES17 } \\
\end{array}$ & 0.61 & 7.52 & 55.03 & & - & 2918 & 1373 & 107.6 & 654.9 & & $\mathrm{QH}$ & 0.0992 \\
\hline & \begin{tabular}{l|l}
18 VES18 \\
\end{tabular} & 1.06 & 6.84 & 15.67 & & - & 403.6 & 151.8 & 62.83 & 692.8 & & $\mathrm{H}$ & 0.454 \\
\hline & 19 VES19 & 1.55 & 4.81 & & - & - & 692.4 & 498.9 & 248.2 & & & Q & 0.0749 \\
\hline & 20 VES20 & 2.55 & 38.1 & & & & 384.2 & 132.9 & 205.5 & & & $\mathrm{H}$ & 0.0716 \\
\hline & 21 VES21 & 0.9 & 4.01 & 6.55 & 15 & 36 & 504.1 & 272.4 & 107 & 72.4 & 201 & QK & 1.3 \\
\hline & \begin{tabular}{|l|l|}
22 & VES22 \\
\end{tabular} & 1.12 & 8.92 & 65.8 & & - & 687.3 & 346.7 & 215.7 & 69.08 & & $Q$ & 0.0911 \\
\hline & 23 VES23 & 1.93 & 51.1 & & & & 314.9 & 78.94 & 143.3 & & & $\mathrm{H}$ & 0.097 \\
\hline & $24 \mid$ VES24 & 0.58 & 9.09 & 76.61 & & & 668.9 & 353.2 & 199.7 & 10.06 & & Q & 0.069 \\
\hline & \begin{tabular}{|l|l|}
25 & VES25 \\
\end{tabular} & 0.97 & 1.84 & & F & - & 306.6 & 307.9 & 204.1 & & & $Q$ & 0.0253 \\
\hline Mean & & 1.48 & 10.39 & 22.10 & 2.72 & 1.44 & 618.74 & 268.42 & 133.00 & 195.10 & 8.04 & & 0.282 \\
\hline
\end{tabular}




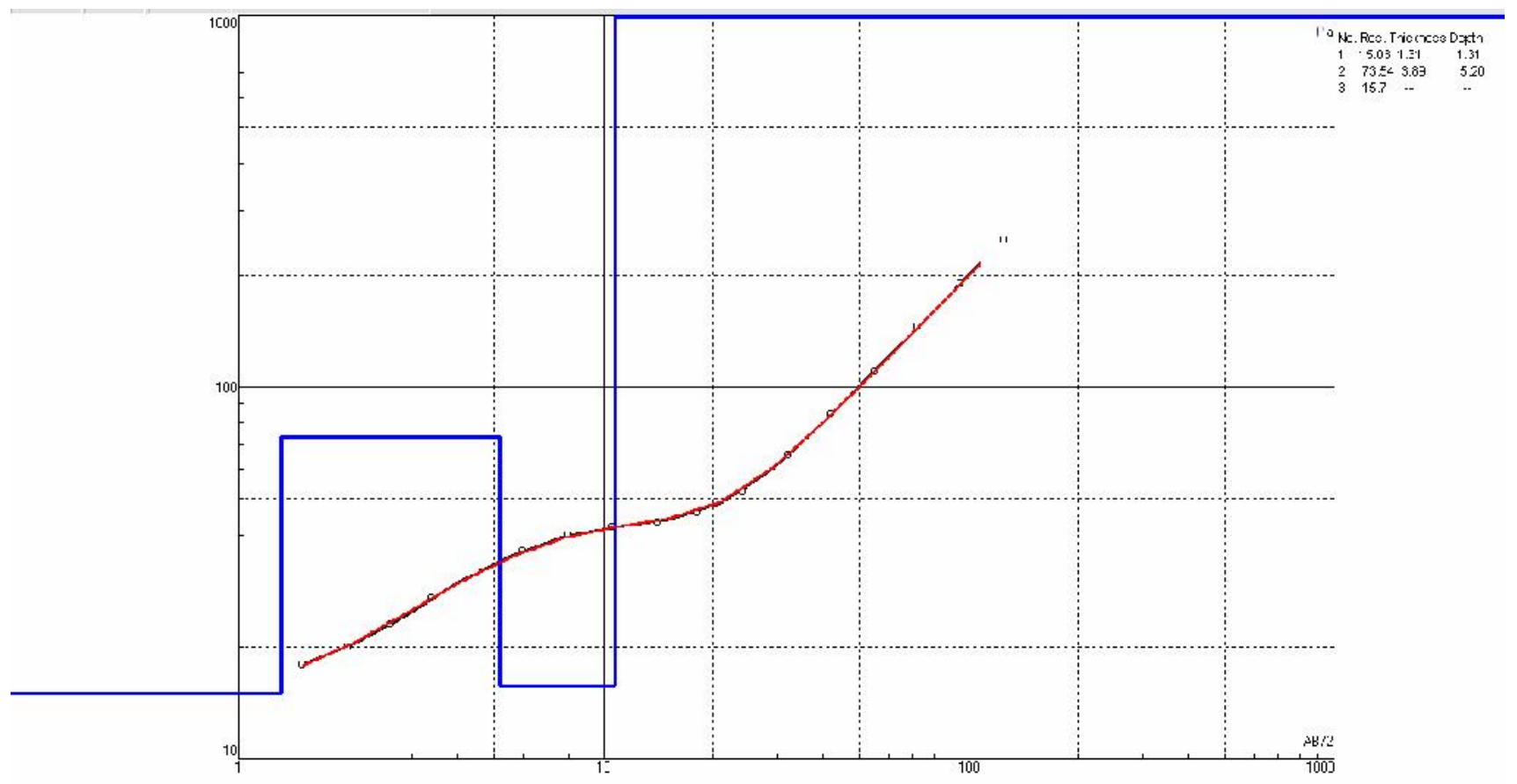

Fig.3.0. A three layers computer interpreted curve from the field data

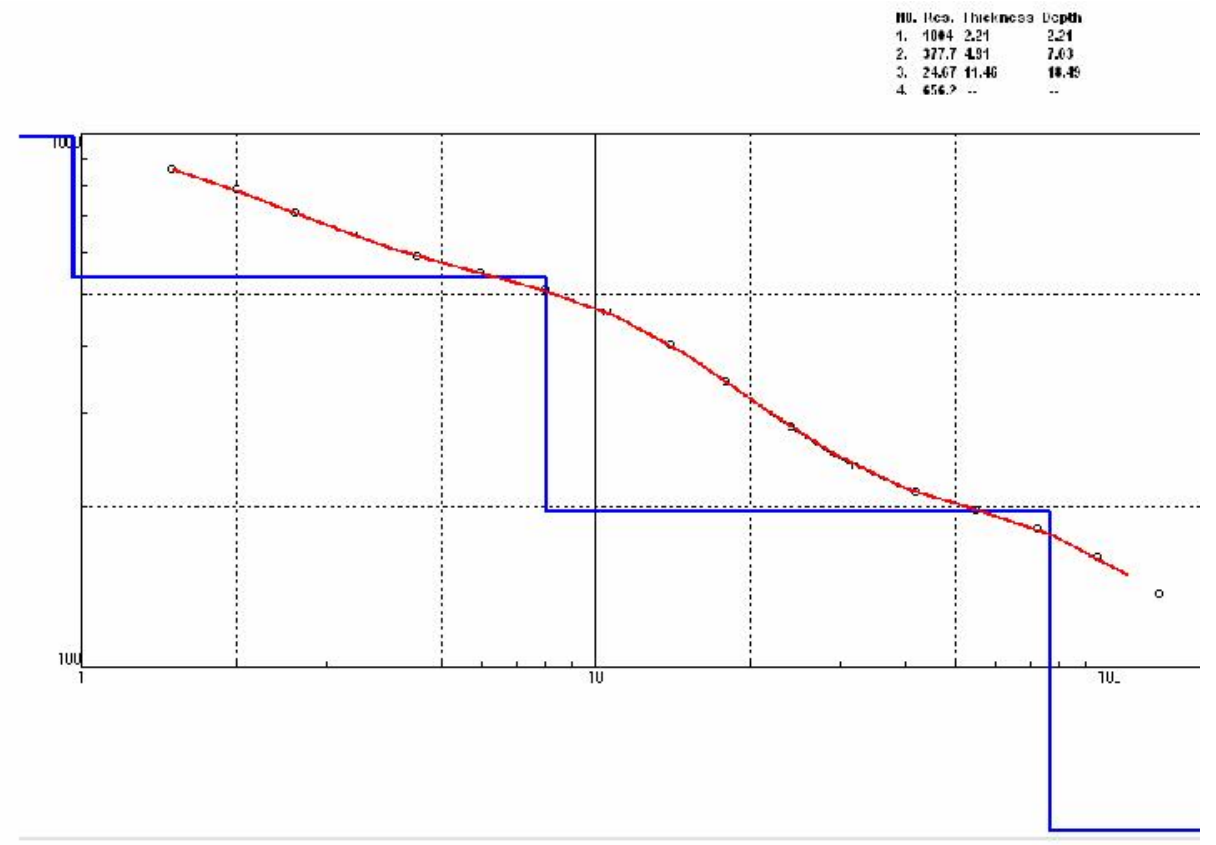

Fig. 3.1 A four layer computer interpreted curve from the field data. 


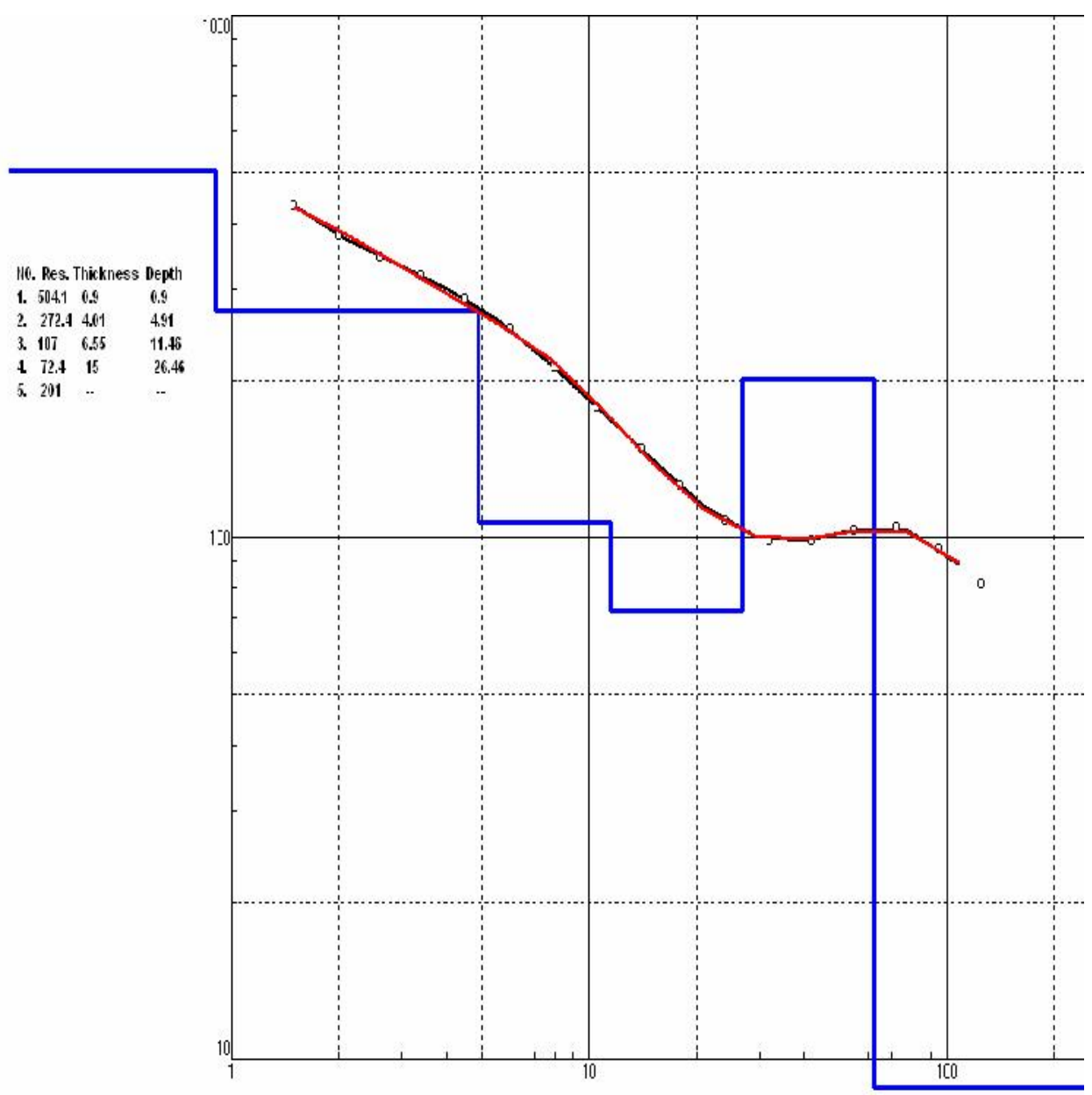

Fig.3.2: A five layer computer interpreted curve from the field data.

\section{Qualitative Analysis}

The area constitutes a non uniform distribution of subsurface lithology in various locations, which is due to discontinuous weathering which is a common characteristic of crystalline rock typical of $\mathrm{H}$-type curve (Offodile, 2002).

Seven different curve types were obtained, these include: $H, Q, A, H A, Q H, K A$ and QK. Eight of the curves are Q-type with resistivity characteristic p1>p2>p3 at VES1, VES 6, VES12, VES13, VES19, VES22, VES24 and VES25.this constitutes about $32 \%$ of the total curves. The $\mathrm{H}$-type curve has resistivity p1 $>$ p2 $<$ p3, it constitutes also $32 \%$ of the total curves and were obtained at VES4, VES5, VES7, VES8, VES10, VES18, VES20 and VES23.The QH-type curve with resistivity $\mathrm{p} 1>\mathrm{p} 2>\mathrm{p} 3<\mathrm{p} 4$, constitutes about $12 \%$ of the total curve and were obtained at VES9, VES15, and VES17. The KA-type curve has a resistivity of $\mathrm{p} 1<\mathrm{p} 2>\mathrm{p} 3<\mathrm{p} 4$, constitutes $8 \%$ of the total curve and was obtained at VES11 and VES 21.

The HA-type curve, with resistivity $p 1>p 2 p<3<p 4$, constitutes $4 \%$ of the total curves and was obtained at VES3.The A-type curve with resistivity p1 $<$ p2<p3 and constitutes also $4 \%$ of the total curves and was obtained at VES2.

\section{DISCUSSION}

The study area is characterized by three -five layers geoelectric sections. The layers have been identified to portray different resistivities resulting from the variations in the lithologic units. The first layer is the top soil with resistivity and thickness range between 90$668 \mathrm{~m}$ and $0.9-2.35$, the layer is zone of aeration, thus serve as medium for recharge.

The second layer is laterite, with a resistivity and thickness range between $668-2198 \mathrm{~m}$ and $0.58-9 \mathrm{~m}$.this is also part of the zone of aeration, but serves as shallow aquifers for hand dug wells.

The third and fourth layers are weathered/fractured Basement with a resistivity and thickness range of 18.1 $107 \mathrm{~m}$ and $10-35 \mathrm{~m}$, these are the expected aquiferous zones.

The fifth layer is slightly weathered-fresh unit, with a resistivity and thickness range from 139-745 mer and $4.08-100 \mathrm{~m}$, it is impervious, if fractured and well connected can serve as aquifer. 
These results agree with geophysical investigation reports by Logpigrand Geotechnics, three functional boreholes were drilled in 2008 by Fatigen Drillers, with mean yield of $2 \mathrm{~L} / \mathrm{sec}$ (Fatigen, 2009) and aquiferous zone corresponds to the weathered/fractured bed rock. The common drilled depth ranges from 25$35 \mathrm{~m}$ depending on the location.

The findings from the hydro-geophysical investigation are summarized on table 2

Table 2. Summary of the result showing groundwater potentials of the area

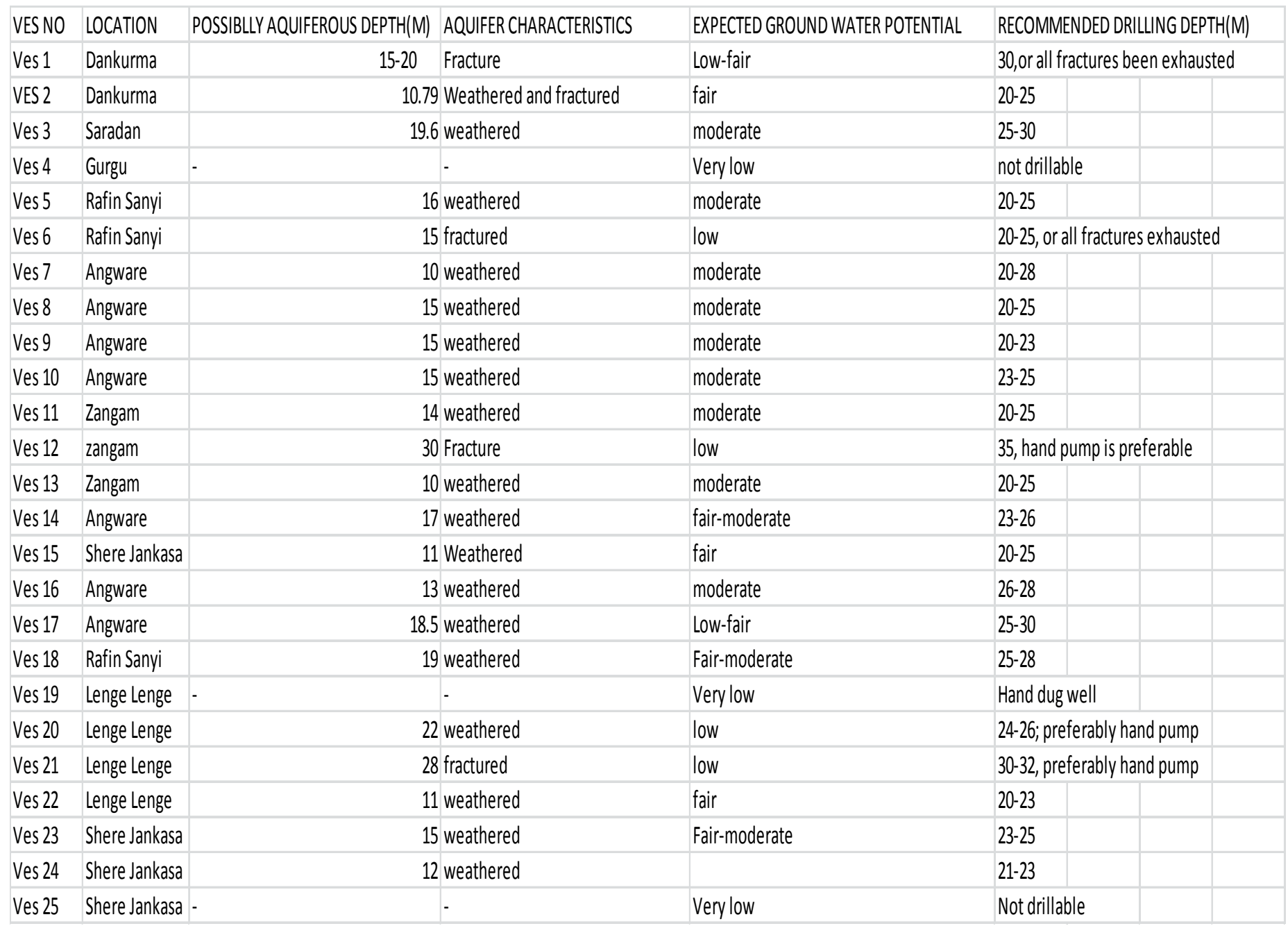

\section{CONCLUSION}

The results of the hydrogeophysical investigation revealed that $56 \%$ of the probe points are aquiferous. These correspond to weathered/fractured unit with thickness between $10-35 \mathrm{~m}$. The study area therefore is capable of producing ground water from borehole when drilled to depths of $20-45 \mathrm{~m}$. There is also need for proper well completion to check any likely contact of surface contamination of groundwater going by the shallow depth of its occurrence.

\section{ACKNOWLEDGEMENT}

The authors are grateful to the management of Longpigrand Geotechnics Ltd Jos, and Mr. Bulus Azi for their kind assistance in the data acquisition.

\section{REFERENCES}

Adanu E. A., 1994. Groundwater Development and Management in the Basement Complex Terrain in Zaria, Kaduna Area.Water Resources vol.4(1\&2): 64-68.

Allied Associate., 2004. Allied ohmega Resistivity meter user's manual, England 15pp

Ariyo S. O., 2007. Hydro-Geophysical Investigation for Groundwater at Atan/Odosenbora Area, Southwestern Nigeria Ife journal of Science.Vol9 (1): 87-92 
Benelt, J. N. Turner, D. C, Ike, E. C and Bowden, P., 1984. The geology of Northern Nigeria Anorogenic Ring Complexes, British Geol. Survey overseas Geology and mineral resources 66pp

Falconer, J. D., 1921. The Geology of the Plateau Tin Fields, Bull. of Geol. Surv. Nigeria No 1.

Fatigen Drillers., 2009. Borehole Report of Angware Town. Fatigen Drillers Ltd Jos.

Jeff, D., 2006. Forum for Groundwater.htt://www.waternet.co.za/groundw ater/(3)

Lonpigrand Geotechnics., 2009. Reports on geophysical surveys unpublished reports Lonpiagrand Geotechnics Ltd Jos.

Lowrie W2001., Fundamentals of Geophysics Cambridge University press London 77-85

Mbiimbe, E. Y. Samaila N. K. and Akanni D. K., 2010. Groundwater Exploration in a Basement Terrain using vertical electrical resistivity sounding (VES): A case study of Rimin Gado town and environs, continental journal of earth science 5 (1) $56-63$

McCurry, P., 1976. A general review of the Precambrian to lower Palaeozoic Rocks of northern Nigeria in Geology of Nigeria (edited by Kogbe C.A.) Elizabeth publ. Co Lagos Nigeria 13-37
Obase, K. O., Olorunfemi, M. O. And Akintorinwa, J. O., 2009. Geophysical and Hydro-chemical Investigation of the Area around a Waste Dump Site in Ile-Ife, Southwestern Nigeria. Global Journal of Geological Sciences. Vol. 7(1). 47-54.

Offodile, M. E., 2002. Groundwater Study and Development in Nigeria. Ehindero Nig Ltd Jos 453pp

Olayinka, A. I. and Oyedele A. A., 2001.Geoelectrical investigation of sites along the proposed Ibadan- Ilorin Dual carriage way. Nigeria journal of Mining and Geology, vol37 (2) 163-175

Olorunfemi, M. O., Ojo, J. S and Akinatunde O. M., 1999. Hydrogeophysical Evaluation of Groundwater potentials of the Akure Metropolis, South Western Nigerian. Nigeria Journal of Mining and Geology" 35 (2) 201-228

Omosuyi, G. O., Ojo, J. S. and Erikanselu, P. A., 2003. Geophysical Investigation for Groundwater Around Obanla-Obakekere in Akure Area within the Basement Complex of South-western Nigeria. Nigeria Journal of mining and Geology vol. 39 (2) 109-116

Wright, E. P., 1971. The Basement Complex Bull. Geol. Surv. of Nigeria No 32, 12-47 